\title{
Carrier detection and prenatal diagnosis in X linked muscular dystrophy using restriction fragment length polymorphisms
}

\author{
M LINDLÖF*†,HKÄ̈̈RIÄINEN* ${ }^{*}, K$ E DAVIES $\S, A N D$ \\ A DE LA CHAPELLE*† \\ From ${ }^{*}$ the Department of Medical Genetics, University of Helsinki; †Folkhälsan Institute of Genetics, \\ Helsinki; $¥$ Department of Medical Genetics, Väestöliitto, Helsinki, Finland; and §Nuffield Department of \\ Clinical Medicine, John Radcliffe Hospital, Oxford.
}

SUMMARY With the aim of offering carrier detection, genetic counselling, and prenatal diagnosis $\dot{\sigma}^{\circ}$ to as many families with Duchenne (DMD) and Becker (BMD) muscular dystrophy as possible, O we used available DNA probes to determine the usefulness of the RFLP approach. We report in

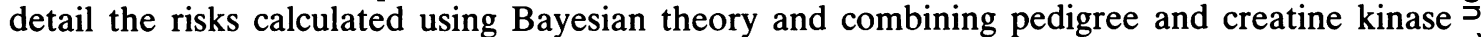
(CK) data with information derived from the RFLP studies. To date we have analysed members $\vec{\nabla}$ of 28 DMD families (10 familial, 18 sporadic) and six BMD families (four familial, two sporadic) $\stackrel{\mathbb{8}}{\circ}$ with the closely linked pERT probes $87-1,87-8$, and 87-15 (DXS164). In addition, key members $\frac{\Phi}{3}$ of all families were analysed with probes D2 (DXS43), C7 (DXS28), 754 (DXS84), and L1.28 (DXS7). Of the 97 females at risk of being carriers (not including 26 obligate carriers), the RFLP results were compatible with carriership in 22 and not in 51 . In 24 females (including 17 mothe of sporadic cases), no information regarding carriership was derived from the RFLP studie There was no disagreement between pedigree information, clearly raised $\mathrm{CK}$ values, and $\mathrm{DN} \AA$ studies. Of 52 obligate or possible carriers under the age of 45 , prenatal diagnosis is possible in 49 Prenatal diagnostic RFLP studies have so far been done in three women. In one sporadic DMD family and one BMD family with three affected males the probands showed a deletion involving $\frac{\mathscr{Q}}{\varnothing}$

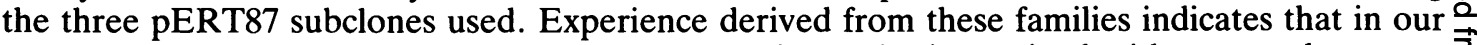
society genetic counselling in X linked muscular dystrophy is received with approval or even 0 enthusiasm in spite of the $5 \%$ error estimate that we have quoted for pERT87 derived results.

$\mathrm{X}$ linked muscular dystrophy is characterised by progressive wasting of the skeletal muscles. On clinical grounds two forms are believed to exist. Duchenne muscular dystrophy (DMD) is much more common and more severe: the patients become wheelchair bound by the age of 12 and usually die of respiratory difficulties by their mid $20 \mathrm{~s}$. Becker muscular dystrophy (BMD) patients are, as a rule, able to walk after 12 years of age and live much longer than DMD patients. ${ }^{1}$

Patients with muscular dystrophy have greatly raised serum levels of the enzyme creatine kinase (CK). Some female carriers have slightly raised CK levels which have been used in carriership determination. ${ }^{2}$ However, approximately one-third of carriers of DMD, and perhaps a larger proportion

Received for publication 5 July 1986. Accepted for publication 14 July 1986. of carriers of BMD, have normal CK levels. This could be explained by the occasional non-random inactivation of the $X$ chromosome carrying the 3 normal allele, instead of the expected random inastivation of either $\mathrm{X}$ chromosome as predicted by $\frac{3}{3}$ the Lyon hypothesis. ${ }^{3}$ In addition to raised serum CK levels, several other manifestations of the gene 5 occur, or have been claimed to occur, in heterozy- $\frac{7}{0}$ gous women. Common to these is that they do not occur in all carriers and thus are of limited value in $N$ carrier detection.

The lack of a reliable test for carrier detection has been a major problem in counselling female rela- $\omega$ tives of patients with DMD and BMD. This is particularly difficult when only one affected maleo occurs in the family. It is believed that about $\Phi$ one-third of sporadic DMD patients arise as a result : of new mutations and are sons of non-carriers. ${ }^{4} \mathrm{~T}$

The gene in which mutations cause DMD was first $\frac{}{\mathrm{D}}$ 
localised to band p21 of the short arm of the X chromosome based on female DMD patients with balanced X;autosome translocations. ${ }^{5}$ At least 12 such females have been reported. Recently, most translocation breakpoints in the $\mathrm{X}$ chromosome have been claimed to be in sub-band $\mathrm{Xp} 21.2$ by detailed cytogenetic studies. ${ }^{6}$ The localisation to $\mathrm{Xp} 21$ has been confirmed by linkage analysis with cloned X chromosome specific DNA sequences. ${ }^{7}$ Several polymorphic DNA probes in the vicinity of Xp21 have been used to study linkage relationships to DMD (table 1). The gene for BMD is probably located in the same area as DMD and linkage studies add weight to the original suggestion that the diseases may be allelic. ${ }^{8} 9$ Until recently, probe 754 (DXS84) detected the closest RFLP with a high heterozygote frequency $(0 \cdot 47)$ and at a genetic distance of about $10 \mathrm{cM}$ from the disease locus. ${ }^{10}$

Carrier determination based on flanking probes such as RC8 (DXS9) and L1.28 (DXS7) combined with serum CK levels has been described. ${ }^{11-13}$ Using these probes, together with probes 754 (DXS84) and $782(D X S 85)$, the risk of a female being a DMD carrier could be lowered from $50 \%$ to $0 \cdot 8 \%$. ${ }^{14}$ Using a total of 11 RFLPs, prenatal diagnosis and carrier detection was performed in two families. ${ }^{15}$ In 24 possible carriers of BMD, DNA probes RC8 (DXS9) and L1.28 (DXS7) were used in conjunction with family data and CK measurements to determine final risk estimates of carrier status using Bayesian calculations. ${ }^{16}$ In two Finnish families with sporadic DMD, risk estimates for carriership could be lowered using probes 754 (DXS84) and D2 (DXS43). ${ }^{17}$

In 1985 Kunkel et al used DNA from a male patient with a small visible deletion to clone DNA segments close to the $\mathrm{X}$ linked muscular dystrophy locus. ${ }^{18} 19$ One clone isolated in this experiment, pERT87, originally 200 bp in length, was expanded by chromosome walking to a $137 \mathrm{~kb}$ continuous stretch of DNA, DXS164. It is located very close to or within the gene(s) involved. This conclusion was made after 88 of 1346 males with X linked muscular dystrophy tested in 25 laboratories throughout the world showed a deletion for all or part of DXS164. ${ }^{20}$ Using a total of seven RFLPs detected by the three subclones pERT87-1, pERT87-8, and pERT87-15, some $95 \%$ of women were found to be heterozygous. ${ }^{20}$ Another polymorphic DNA segment, XJ1.1, located near DXS164, has been isolated by cloning the breakpoint of an $\mathrm{X} ; 21$ translocation chromosome from a female with DMD. ${ }^{21}$ These closely linked probes are extremely useful in the study of DMD and BMD and represent a major advance in the diagnostic procedures involving $\mathrm{X}$ linked muscular dystrophy.
The aim of this investigation was to use available probes to determine, in an unselected series of patients and families with $\mathrm{X}$ linked muscular dystrophy, the usefulness of the RFLP approach to carrier detection and prenatal diagnosis.

\section{Patients and methods}

\section{PATIENTS}

An attempt was made to ascertain as many patients as possible with $\mathrm{X}$ linked muscular dystrophy in Finland (population almost 5 million). To achieve this, neurologists and paediatricians known to have a particular interest in these diseases were contacted. Moreover, all centres for genetic counselling in Finland were contacted, as well as those hospitals and institutions for the care of the physically handicapped in which persons with muscular dystrophy are treated.

At the beginning of 1984, 72 families with DMD or BMD patients had been reported to us. In order to establish contact with these patients, a letter was sent out to the patients or their parents outlining the new RFLP approach to carrier detection and prenatal diagnosis. As a result, 42 families replied that they were interested in taking part in the study. So far we have studied 34 families. In 14 of these the disease was familial and in the rest the patients were sporadic. Altogether $33 \mathrm{DMD}$ patients from 28 families and 14 BMD patients from six families were studied. We estimate that one-third of all cases in Finland are included in our sample. Samples from 292 subjects were obtained in total, including 47 affected males.

\section{CLINICAL CLASSIFICATION}

The patients were considered to have muscular dystrophy if they fulfilled the following criteria ${ }^{22}$ : (1) progressive muscular weakness of childhood onset; (2) pseudohypertrophy of the calf muscles; (3) very high levels (50 times or more) of serum CK; (4) myopathic changes on electromyography; and (5) typical histological findings in muscle. In families where the disease showed clear $\mathrm{X}$ linked inheritance, patients were accepted as having muscular dystrophy even if they had been incompletely studied. The possibility of the rare limb-girdle muscular dystrophy in the sporadic cases was ignored as long as the clinical features were compatible with DMD or BMD. The disorder was classified as Duchenne type muscular dystrophy if the patient was confined to a wheelchair by the age of 12 and Becker type if the progression was slower.

DNA ANALYSIS

DNA was extracted according to a previously 
TABLE 1 Polymorphic DNA markers from the short arm of the $X$ chromosome used in this study. ${ }^{10} 20$

\begin{tabular}{|c|c|c|c|c|c|c|c|}
\hline Locus & Probe & $\begin{array}{l}\text { Genetic } \\
\text { distance to } \\
D M D / B M D(c M)\end{array}$ & $\begin{array}{l}\text { Restriction enzyme } \\
\text { detecting RFLP }\end{array}$ & Alleles & $\begin{array}{l}\text { Allele } \\
\text { length (kb) }\end{array}$ & $\begin{array}{l}\text { Allele } \\
\text { frequency }\end{array}$ & Reference \\
\hline$D X S 28$ & $\mathrm{C7}$ & 10 & EcoRV & $\begin{array}{l}\text { E1 } \\
\text { E2 }\end{array}$ & $\begin{array}{l}8 \cdot 0 \\
7 \cdot 5\end{array}$ & $\begin{array}{l}0 \cdot 15 \\
0 \cdot 85\end{array}$ & 27 \\
\hline & & & $X m n I$ & $\begin{array}{l}\text { R1 } \\
\text { R2 }\end{array}$ & $\begin{array}{l}8 \cdot 7 \\
7 \cdot 5\end{array}$ & $\begin{array}{l}0 \cdot 66 \\
0 \cdot 34\end{array}$ & \\
\hline & pERT87-8 & & Bst XI & $\begin{array}{l}\text { V1 } \\
\text { V2 }\end{array}$ & $\begin{array}{l}4 \cdot 4 \\
2 \cdot 2\end{array}$ & $\begin{array}{l}0 \cdot 60 \\
0 \cdot 40\end{array}$ & \\
\hline & & & TaqI & $\begin{array}{l}\text { W1 } \\
\text { W2 }\end{array}$ & $\begin{array}{l}3 \cdot 8 \\
2 \cdot 7+1 \cdot 1\end{array}$ & $\begin{array}{l}0 \cdot 29 \\
0 \cdot 71\end{array}$ & \\
\hline & & & TaqI & $\begin{array}{l}\mathrm{S} 1 \\
\mathrm{~S} 2\end{array}$ & $\begin{array}{l}3 \cdot 3 \\
3 \cdot 1\end{array}$ & $\begin{array}{l}0 \cdot 33 \\
0 \cdot 67\end{array}$ & \\
\hline & & & $X m n I$ & $\begin{array}{l}\mathrm{T} 1 \\
\mathrm{~T} 2\end{array}$ & $\begin{array}{l}2 \cdot 8 \\
1 \cdot 6+1 \cdot 2\end{array}$ & $\begin{array}{l}0 \cdot 32 \\
0 \cdot 68\end{array}$ & \\
\hline$D X S 84$ & 754 & 10 & PstI & $\begin{array}{l}\text { A1 } \\
\text { A2 }\end{array}$ & $\begin{array}{r}12 \cdot 0 \\
9 \cdot 0\end{array}$ & $\begin{array}{l}0 \cdot 62 \\
0 \cdot 38\end{array}$ & 14 \\
\hline$D X S 7$ & $\mathrm{~L} 1 \cdot 28$ & 20 & TaqI & $\begin{array}{l}\mathrm{F} 1 \\
\mathrm{~F} 2\end{array}$ & $\begin{array}{r}12 \cdot 0 \\
9 \cdot 0\end{array}$ & $\begin{array}{l}0 \cdot 68 \\
0 \cdot 32\end{array}$ & 29 \\
\hline
\end{tabular}

Family 1

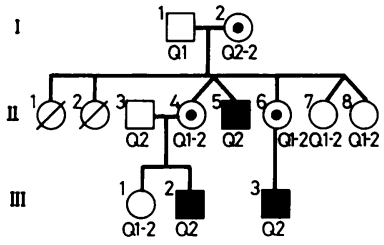

Family 4

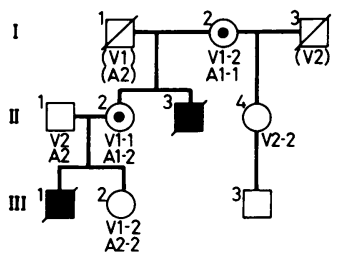

Family 7

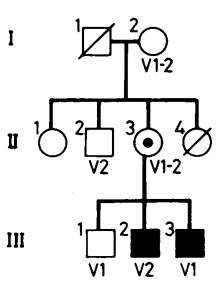

Family 2

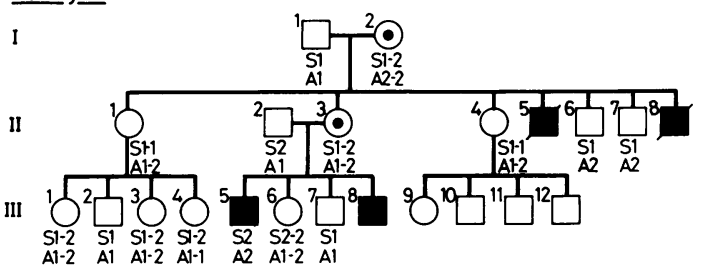

Family 3

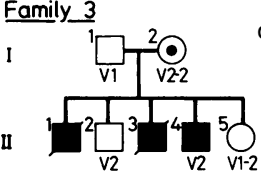

Family 6

Family 5

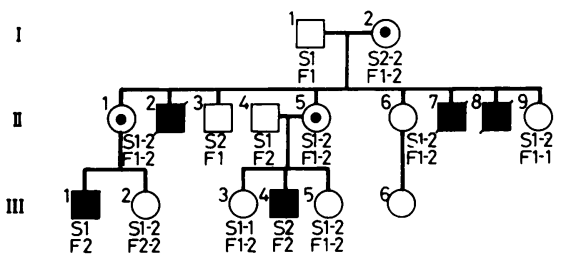

Family $\underline{9}$

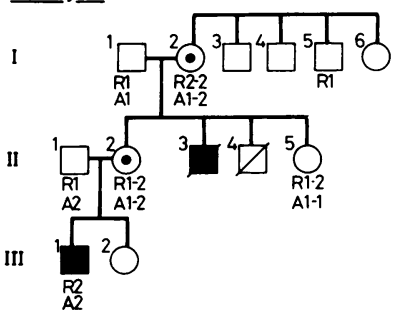

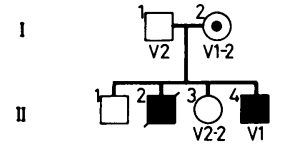

Affected male

(-) Obligate carrier female

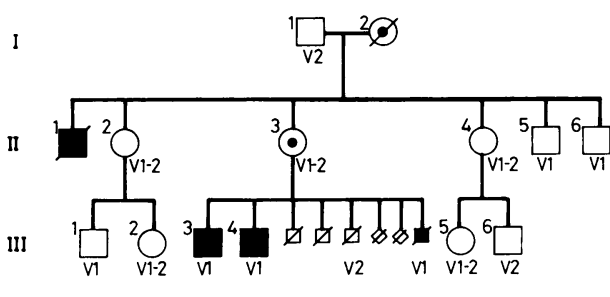


described method from heparinised blood, fibroblasts, cultured amniotic cells obtained by amniocentesis, ${ }^{23}$ or chorionic villi. ${ }^{24}$ DNA was digested to completion separately with the appropriate restriction enzymes according to the manufacturer's recommendations. Electrophoresis, Southern blotting, and hybridisation were performed as previously described. ${ }^{25}$

Because the four RFLPs detected with pERT87-1 and pERT87-8 display a high degree of linkage disequilibrium, ${ }^{20}$ we first analysed key women in each family with the frequent $B s t \mathrm{XI}$ polymorphism of pERT87-8. If the key person was homozygous she was tested for the $X m n I$ polymorphism of pERT87-1. Remaining homozygotes were analysed for the three RFLPs detected by probe pERT87-15. Key members of all families were also analysed with the less closely linked probes D2, C7, 754, and L1.28 (table 1).

\section{RISK ESTIMATES}

The risk of carrying the gene for muscular dystrophy was assessed for every available first degree female relative of either an affected male or a carrier female using data obtained from the pedigree and informa- tion from serum CK measurements. CK had been determined at different times and in different laboratories so methods and normal values varied. The practice had usually been to take three or more measurements. The risk was calculated using Bayesian theory 2230 and assuming that two-thirds of carriers of DMD and BMD have raised levels of serum CK. The risk for a female was then calculated starting from her mother's risk, determined as explained, then using the RFLP information, and finally combining the information from her own $\mathrm{CK}$ measurements by the Bayesian method. Genetic counselling was given or offered to every family. Second and third degree female relatives were studied and counselled if they so wished.

\section{Results}

The 34 families studied were divided into two groups according to the clinical type of muscular dystrophy. There were 28 families with the Duchenne type and six families with the Becker type. Both groups were divided into two classes, familial and sporadic. The pedigrees and segregation of pERT87 alleles are shown in fig 1 . In most families there was informa-
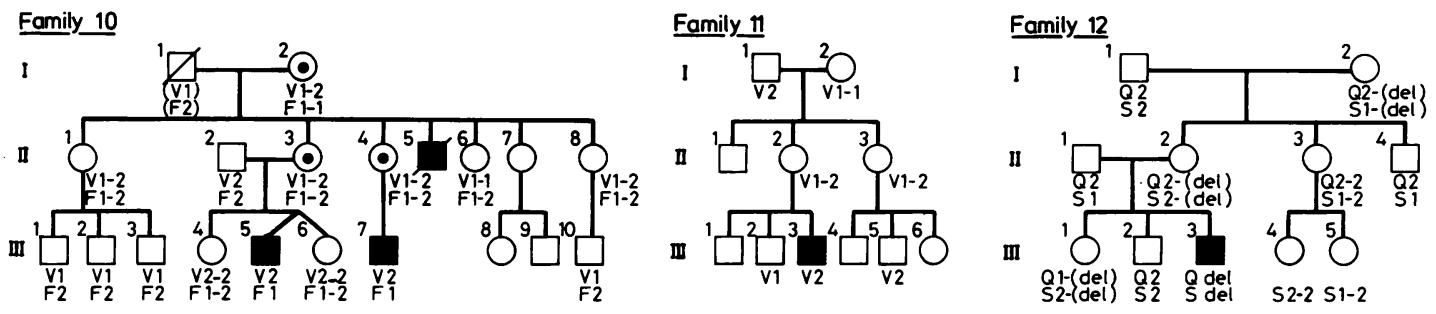

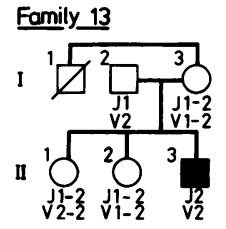

Family 17

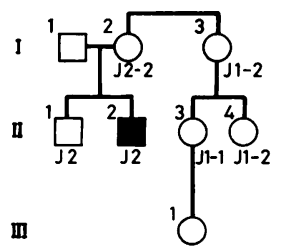

Fomily 14

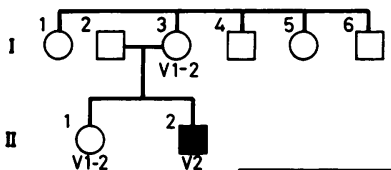

Affected male

Obligate carrier female

Family 18

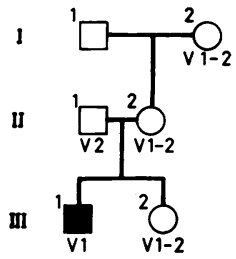

Family 19

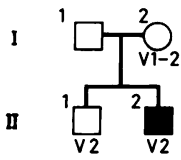

Family 16

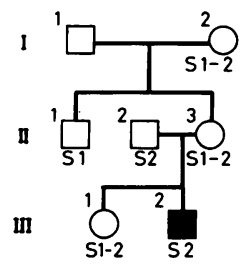

Family 15

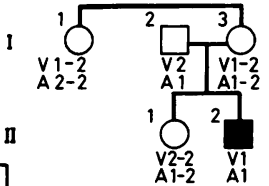

Family 20

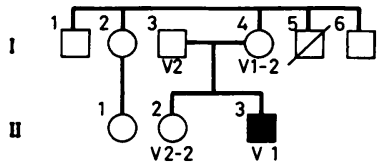


Family 21

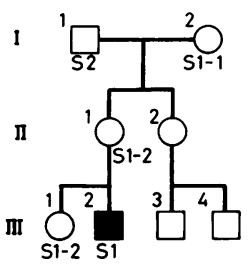

Family 22

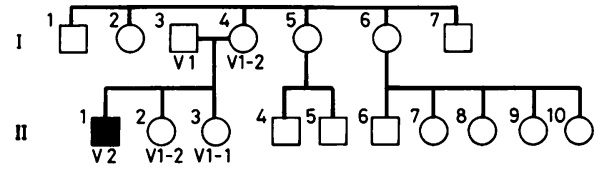

Affected male

- Obligate carrier female

Family 24

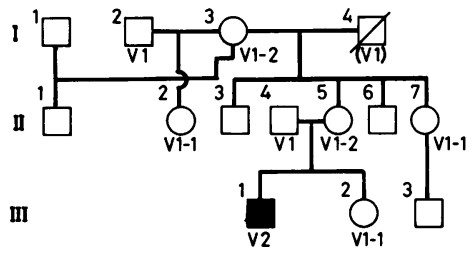

Family 25

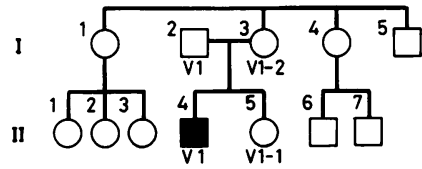

III

Family 27

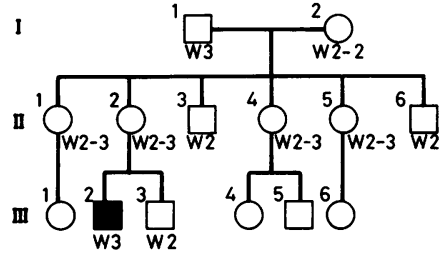

Family 28

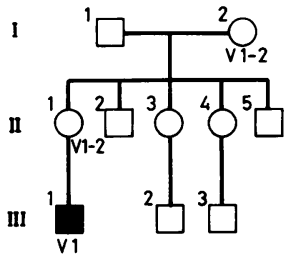

Family_23

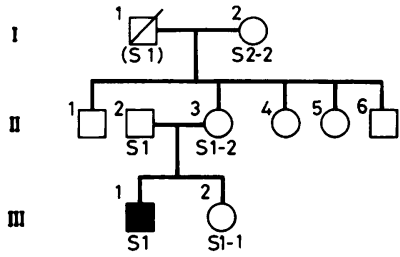

Family 26

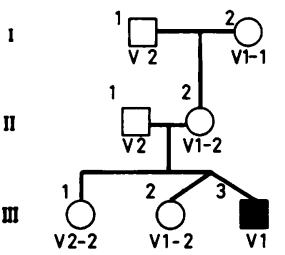

tive segregation for one or several of the other four probes used (data not shown in detail). We did not attempt to make risk estimates based on both pERT87 and other probes because it cannot yet be determined on which side of a particular mutation an informative pERT87 probe is located. However, in four families, information on carriership was obtained with pERT87 RFLPs in some women and with other probes in other women. These additional RFLP data are shown in the pedigrees as follows: probe $754(D X S 84)$ in families 4,8 , and 15 and probe $\mathrm{L} 1 \cdot 28(D X S 7)$ in family 5 . In one family (17) the only probe showing informative segregation was D2 (DXS43). Of 52 obligate or possible carriers under the age of 45 , prenatal diagnosis is possible in 49. The probes for which these women are heterozygous are: pERT87: 45 females; L1-28: two females (family 10); 754: one female (family 2); and D2: one female (family 13). When counselling regarding prenatal diagnosis is given to females who are heterozygous only for the distant probes (D2 and L1.28), the high error rate due to recombination must be stressed. The segregation of $\mathrm{L} 1.28$ in family 10,754 in family 2 , and D2 in family 13 is shown in the pedigrees.

Allowing for the possibility that recombination occurs between a pERT 87 probe and the disease locus with a $5 \%$ frequency, ${ }^{20}$ exclusion or confirmation of carriership could not be done with certainty. On the other hand, the $5 \%$ recombination value is a maximum estimate based on a large and very heterogeneous group of patients. In this paper, we use the term carriership 'excluded' whenever the calculated risk was $5 \%$ or less. The accuracy with which 'confirmation' of carriership can be determined is different in different situations, such as familial versus sporadic disease, whether CK was determined or not, and what information was obtained from RFLPs. In prenatal diagnostic determinations, we have also taken care to point out the

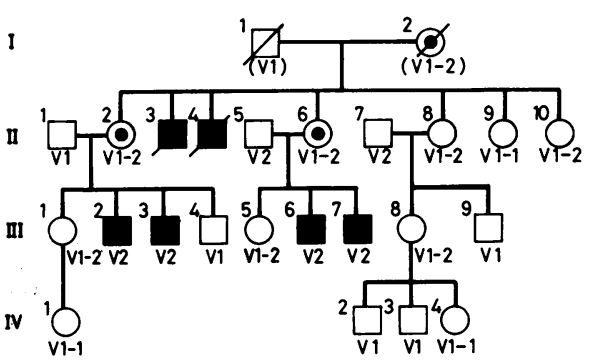


Family 30

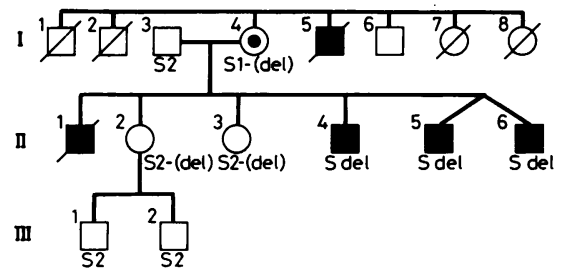

Family 32

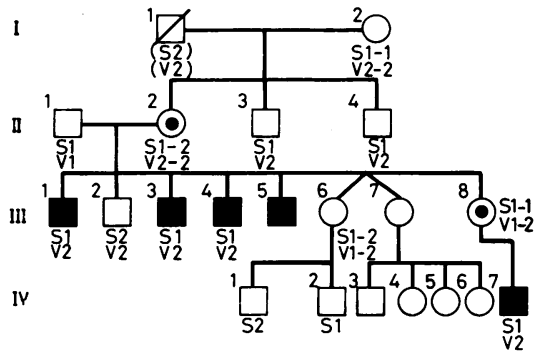

Family 31

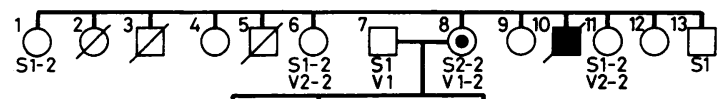

n

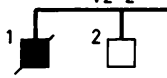

Affected male

Obligate carrier female

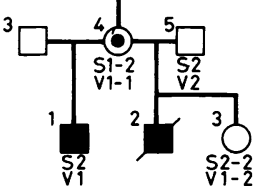

Family 34

Family 33

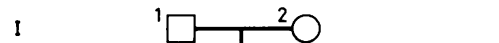

I

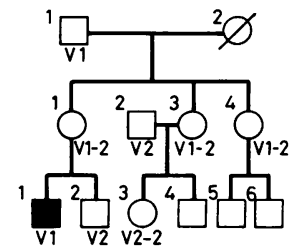

FIG 1 Pedigrees of the 34 families studied. Pedigrees 1 to 10 represent familial DMD, 11 to 28 families with one sporadic DMD case, 29 to 32 families with familial BMD, and 33 to 34 families with one sporadic BMD case. Segregating alleles for $D X S 164$ and other relevant loci (see text) are shown by a letter (RFLP) and numbers (alleles). Symbols in parentheses indicate inferred rather than determined alleles. The probe and allele symbols are as follows: $J=D 2, R=p E R T 87-1(X m n I)$, $V=p E R T 87-8(B s t X I), W=p E R T 87-8(T a q I), Q=p E R T 87-15(B a m H I), S=p E R T 87-15($ TaqI $)$, and $A=754.1=$ larger fragment size, $2=$ smaller fragment size (table 1). The W3 allele in family 27 denotes a previously unobserved allele with fragment sizes of $3 \cdot 8+1 \cdot 1 \mathrm{~kb}$ using $\mathrm{pERT87-8(TaqI)}$. Del=deletion of a particular probe.

$5 \%$ error rate. These questions are dealt with in more detail below.

DUCHENNE MUSCULAR DYSTROPHY, FAMILIAL There were 10 DMD families with more than one affected male. A total of 15 affected males, 19 obligate carrier females, and 28 females at risk of being carriers were studied. Carriership could be excluded in 12 females using pERT87 probes, in two females with 754 , and one female with L1-28. RFLP segregation was compatible with carriership in six females using pERT87 probes and in two using L1.28. In the remaining five females the RFLP study did not contribute to carrier determination. For females under the age of 45 we were able to offer prenatal diagnosis to nine of 10 obligate carriers and all 13 females with a greater than $10 \%$ risk. If the risk of being a carrier was less than $10 \%$, prenatal diagnosis was not offered if not specially asked for. In 19 of these 22 women (including obligate carriers) the diagnosis could be made by using an RFLP of pERT87, in two using L1.28, and in one using 754.
In this group of families, two prenatal determinations have so far been performed. The carrier risk estimates and the possibilities of prenatal diagnosis are shown in table 2 .

\section{Example: family 9}

In this extraordinary family there are two affected boys, now aged 15 and 11. After the birth in 1975 of the second affected son the mother underwent termination of pregnancy three times after a male fetus had been diagnosed through amniocentesis. Thereafter the mother had had two spontaneous abortions. When she became pregnant for the eighth time in early 1985 RFLP studies were initiated on the living family members and also on frozen amniotic cells from the third aborted male fetus. RFLP analysis with the BstXI RFLP of pERT87-8 showed that both affected males carried the V1 allele. The 1985 fetus also carried the $\mathrm{X}$ chromosome with the V1 allele and the family decided to have the pregnancy terminated after an affected fetus had been predicted. DNA obtained from the 
previously aborted fetus carried the $\mathrm{X}$ chromosome with the V2 allele indicating that the fetus had probably been unaffected. Three other males (II.5, II.6, and III.1) also carry the V1 allele. This shows that the mother's mother (now dead), who was an obligate carrier, must have been homozygous for the

V1 allele, because the V1 allele of II.2 and her healthy son (III.1) is on an $\mathrm{X}$ chromosome not carrying DMD. Thus, II.2 and her daughter (III.2) are at low risk of being carriers. Carriership could

TABLE 2 Carrier risk estimates and possibility of prenatal diagnosis using family data, CK measurements, and DNA studies in females at risk of being carriers in familial DMD.

\begin{tabular}{|c|c|c|c|c|c|c|}
\hline Family & Subject & $\begin{array}{l}\text { Pedigree } \\
\text { risk (\%) }\end{array}$ & $\begin{array}{l}\text { Pedigree + } \\
\text { CK risk (\%) }\end{array}$ & $\begin{array}{l}\text { Carriership } \\
\text { information } \\
\text { provided by } \\
\text { RFLP }\end{array}$ & $\begin{array}{l}\text { Pedigree + } \\
C K+D N A \\
\text { risk }(\%)\end{array}$ & $\begin{array}{l}\text { Future pregnancies } \\
\text { informative with } \\
\text { an RFLP probe }\end{array}$ \\
\hline 1 & \begin{tabular}{r|} 
I. 2 \\
II. 4 \\
II. 6 \\
II. \\
II. 8 \\
III. 1 \\
\end{tabular} & $\begin{array}{r}100 \\
100 \\
100 \\
50 \\
50 \\
50\end{array}$ & $\begin{array}{l}26 \\
93\end{array}$ & $\begin{array}{l}\text { OC } \\
\text { OC } \\
\text { OC } \\
\mathrm{NI} \\
\mathrm{NI} \\
\mathrm{NC}(\mathrm{Q})\end{array}$ & $\begin{array}{r}26 \\
93 \\
5\end{array}$ & $\begin{array}{l}>45 \text { years } \\
+(Q) \\
+(Q) \\
+(Q) \\
+(Q) \\
\text { NC }\end{array}$ \\
\hline 2 & \begin{tabular}{r|} 
I. 2 \\
II. 1 \\
II. 3 \\
II. .4 \\
III. 1 \\
III .3 \\
III. 4 \\
III. 6
\end{tabular} & $\begin{array}{r}100 \\
33 \\
100 \\
11 \\
17 \\
17 \\
17 \\
50\end{array}$ & 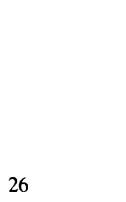 & $\begin{array}{l}\text { OC } \\
\text { NC(S) } \\
\text { OC } \\
\text { NC(S) } \\
\text { NC(S) } \\
\text { NC(S) } \\
\text { NC(S) } \\
\text { C(S) }\end{array}$ & $\begin{array}{r}5 \\
<1 \\
3 \\
3 \\
<1 \\
87\end{array}$ & $\begin{array}{l}>45 \text { years } \\
\mathrm{NC} \\
+(\mathrm{S}) \\
\mathrm{NC} \\
\mathrm{NC} \\
\mathrm{NC} \\
\mathrm{NC} \\
+(\mathrm{A})\end{array}$ \\
\hline 3 & $\begin{array}{r}\text { I. } 2 \\
\text { II. } .5\end{array}$ & $\begin{array}{r}100 \\
50\end{array}$ & 26 & $\begin{array}{l}\mathrm{OC} \\
\mathrm{NI}\end{array}$ & 26 & $\begin{array}{l}>45 \text { years } \\
+(V)\end{array}$ \\
\hline 4 & $\begin{array}{r}\text { I. } 2 \\
\text { II. } .2 \\
\text { II. } .4 \\
\text { III } .2\end{array}$ & $\begin{array}{r}100 \\
100 \\
33 \\
50\end{array}$ & 15 & $\begin{array}{l}\text { OC } \\
\text { OC } \\
\text { NC(V) } \\
\text { NC(A) }\end{array}$ & $\begin{array}{l}1 \\
5\end{array}$ & $\begin{array}{l}>45 \text { years } \\
>45 \text { years } \\
\mathrm{NC} \\
\mathrm{NC}\end{array}$ \\
\hline 5 & $\begin{array}{r}\text { I. } 2 \\
\text { II. } 1 \\
\text { II. } .5 \\
\text { II. } 6 \\
\text { II } .9 \\
\text { III } .2 \\
\text { III. } 3 \\
\text { III. } .5\end{array}$ & $\begin{array}{r}100 \\
100 \\
100 \\
50 \\
50 \\
50 \\
50 \\
50\end{array}$ & 26 & $\begin{array}{l}\text { OC } \\
\text { OC } \\
\text { OC } \\
\text { C(F) } \\
\text { NC(F) } \\
\text { C(F) } \\
\text { NC(S) } \\
\text { C(S) }\end{array}$ & $\begin{array}{r}58 \\
20 \\
80 \\
5 \\
95\end{array}$ & $\begin{array}{l}>45 \text { years } \\
+(\mathrm{S}) \\
+(\mathrm{S}) \\
+(\mathrm{S}) \\
\mathrm{NC} \\
+(\mathrm{S}) \\
\mathrm{NC} \\
+(\mathrm{S})\end{array}$ \\
\hline 6 & $\begin{array}{r}\text { I. } 2 \\
\text { II. } 3\end{array}$ & $\begin{array}{r}100 \\
50\end{array}$ & 26 & $\begin{array}{l}\mathrm{OC} \\
\mathrm{NC}(\mathrm{V})\end{array}$ & 2 & $\begin{array}{l}>45 \text { years } \\
\mathrm{NC}\end{array}$ \\
\hline 7 & II. 3 & 100 & & OC & & $\mathrm{NI}^{*}$ \\
\hline 9 & $\begin{array}{r}\text { II. } 2 \\
\text { II } .3 \\
\text { II. } 4 \\
\text { III } .2 \\
\text { III } .5\end{array}$ & $\begin{array}{r}33 \\
100 \\
33 \\
17 \\
17\end{array}$ & & $\begin{array}{l}\mathrm{NC}(\mathrm{V}) \\
\mathrm{OC} \\
\mathrm{NI} \\
\mathrm{NC}(\mathrm{V}) \\
\mathrm{NI}\end{array}$ & $\begin{array}{r}5 \\
\\
33 \\
3 \\
17\end{array}$ & $\begin{array}{l}\text { NC } \\
+(\mathrm{V}) \\
+(\mathrm{V}) \\
\mathrm{NC} \\
+(\mathrm{V})\end{array}$ \\
\hline 10 & \begin{tabular}{r|} 
II.2 \\
II. 1 \\
II. .3 \\
II. .4 \\
II .6 \\
II .8 \\
III .4 \\
III .6
\end{tabular} & $\begin{array}{r}100 \\
11 \\
100 \\
100 \\
50 \\
33 \\
50 \\
50\end{array}$ & $\begin{array}{l}26 \\
87 \\
93 \\
93\end{array}$ & $\begin{array}{l}\text { OC } \\
C(V) \\
O C \\
\text { OC } \\
\text { NC(V) } \\
C(V) \\
C(V) \\
C(V)\end{array}$ & $\begin{array}{c}2 \\
>99 \\
>99 \\
>99\end{array}$ & $\begin{array}{l}>45 \text { years } \\
+(\mathrm{V}) \\
+(\mathrm{V}) \\
+(\mathrm{V}) \\
\mathrm{NC} \\
+(\mathrm{V}) \\
+(\mathrm{F}) \\
+(\mathrm{F})\end{array}$ \\
\hline
\end{tabular}

$\mathrm{C}=$ compatible with carriership.

$\mathrm{NC}=$ not compatible with carriership.

$\mathrm{OC}=$ obligate carrier.

$\mathrm{NI}=$ no information.

$+=$ informative.

The RFLP used to provide information is shown in parentheses.

For abbreviations of RFLPs see table 1.

*Prenatal diagnosis not possible due to apparent recombination in this family (see Discussion). 
not be determined in the mother's younger sister (II.4) since her only son, who is healthy, has the $\mathrm{X}$ chromosome with the V2 allele.

DUCHENNE MUSCULAR DYSTROPHY, SPORADIC There were 18 families with only one affected male and a negative family history. Typically, RFLP studies can usually neither confirm nor exclude carriership in the mothers of the probands in this category. An exception is the mother in family 19, heterozygous for the BstXI RFLP of pERT87-8. She has an affected and a healthy son and both have inherited the same allele. The affected male is probably the result of a new mutation and the mother is not a carrier of DMD. The segregation of RFLP alleles often allows carriership to be excluded

TABLE 3 Carrier risk estimates and possibility of prenatal diagnosis using family data, CK measurements, and DNA studies in females at risk of being carriers in sporadic DMD.

\begin{tabular}{|c|c|c|c|c|c|c|}
\hline Family & Subject & $\begin{array}{l}\text { Pedigree } \\
\text { risk }(\%)\end{array}$ & $\begin{array}{l}\text { Pedigree + } \\
\text { CK risk }(\%)\end{array}$ & $\begin{array}{l}\text { Carriership } \\
\text { information } \\
\text { provided } \\
\text { by } R F L P\end{array}$ & $\begin{array}{l}\text { Pedigree + } \\
C K+D N A \\
\text { risk }(\%)\end{array}$ & $\begin{array}{l}\text { Future pregnancies } \\
\text { informative with } \\
\text { an RFLP probe }\end{array}$ \\
\hline 11 & $\begin{array}{l}\text { II. } 2 \\
\text { II. } 3\end{array}$ & $\begin{array}{r}27 \\
3\end{array}$ & $\begin{array}{r}83 \\
4\end{array}$ & $\begin{array}{l}\text { NI } \\
\text { NC(V) }\end{array}$ & $\begin{array}{l}83 \\
<1\end{array}$ & $\begin{array}{l}+(\mathrm{V}) \\
\mathrm{NC}\end{array}$ \\
\hline 12 & $\begin{array}{r}\text { II. } 2 \\
\text { II. } 3 \\
\text { III. } 1 \\
\text { III. } 4 \\
\text { III } .5\end{array}$ & $\begin{array}{r}43 \\
7 \\
22 \\
4 \\
4\end{array}$ & $\begin{array}{r}21 \\
4 \\
62\end{array}$ & $\begin{array}{l}\mathrm{C}(\mathrm{S}) \\
\mathrm{NC}(\mathrm{S}) \\
\mathrm{C}(\mathrm{Q}) \\
\mathrm{NC}(\mathrm{S}) \\
\mathrm{NC}(\mathrm{S})\end{array}$ & $\begin{array}{r}100 \\
0 \\
100 \\
0 \\
0\end{array}$ & $\begin{array}{l}+(\mathrm{S}) \\
\mathrm{NC} \\
+(\mathrm{S}) \\
\mathrm{NC} \\
\mathrm{NC}\end{array}$ \\
\hline 13 & $\begin{array}{l}\text { I. } 3 \\
\text { II. } 1 \\
\text { II } .2\end{array}$ & $\begin{array}{l}60 \\
30 \\
30\end{array}$ & $\begin{array}{r}35 \\
7 \\
7\end{array}$ & $\begin{array}{l}\text { NI } \\
\mathrm{C}(\mathrm{V}) \\
\mathrm{NC}(\mathrm{V})\end{array}$ & $\begin{array}{r}35 \\
15 \\
1\end{array}$ & $\begin{array}{l}>45 \text { years } \\
+(\mathrm{J}) \\
\mathrm{NC}\end{array}$ \\
\hline 14 & $\begin{array}{r}\text { I. } 3 \\
\text { II. } 1\end{array}$ & $\begin{array}{l}56 \\
28\end{array}$ & $\begin{array}{l}30 \\
15\end{array}$ & $\begin{array}{l}\mathrm{NI} \\
\mathrm{NI}\end{array}$ & $\begin{array}{l}30 \\
15\end{array}$ & $\begin{array}{l}+(V) \\
+(V)\end{array}$ \\
\hline 15 & $\begin{array}{r}I .1 \\
\text { I. } 3 \\
\text { II } .1\end{array}$ & $\begin{array}{l}16 \\
60 \\
30\end{array}$ & $\begin{array}{l}95 \\
24\end{array}$ & $\begin{array}{l}\mathrm{NC}(\mathrm{A}) \\
\mathrm{NI} \\
\mathrm{NC}(\mathrm{V})\end{array}$ & $\begin{array}{r}2 \\
95 \\
2\end{array}$ & $\begin{array}{l}\mathrm{NC} \\
+(\mathrm{V}) \\
\mathrm{NC}\end{array}$ \\
\hline 16 & $\begin{array}{r}\text { II. } 3 \\
\text { III. } 1\end{array}$ & $\begin{array}{l}60 \\
30\end{array}$ & $\begin{array}{r}35 \\
7\end{array}$ & $\begin{array}{l}\text { NI } \\
\mathrm{NC}(\mathrm{S})\end{array}$ & $\begin{array}{r}35 \\
1\end{array}$ & $\begin{array}{l}>45 \text { years } \\
\text { NC }\end{array}$ \\
\hline 17 & $\begin{array}{r}1.2 \\
1.3 \\
\text { II. } 3 \\
\text { II. } 4\end{array}$ & $\begin{array}{r}50 \\
13 \\
7 \\
7\end{array}$ & $\begin{array}{r}26 \\
7 \\
4 \\
4\end{array}$ & $\begin{array}{l}\mathrm{NI} \\
\mathrm{NC}(\mathrm{J}) \\
\mathrm{NC}(\mathrm{J}) \\
\mathrm{NC}(\mathrm{J})\end{array}$ & $\begin{array}{r}26 \\
1 \\
<1 \\
<1\end{array}$ & $\begin{array}{l}>45 \text { years } \\
\text { NC } \\
\text { NC } \\
\text { NC }\end{array}$ \\
\hline 18 & $\begin{array}{r}\text { II } .2 \\
\text { III } .2\end{array}$ & $\begin{array}{l}67 \\
33\end{array}$ & $\begin{array}{l}96 \\
91\end{array}$ & $\begin{array}{l}\text { NI } \\
\mathrm{C}(\mathrm{V})\end{array}$ & $\begin{array}{l}96 \\
96\end{array}$ & $\begin{array}{l}+(\mathrm{V}) \\
+(\mathrm{V})\end{array}$ \\
\hline 19 & I. 2 & 50 & 26 & $\mathrm{NC}(\mathrm{V})$ & 2 & $\mathrm{NC}$ \\
\hline 20 & $\begin{array}{r}\text { I. } 4 \\
\text { II } .2\end{array}$ & $\begin{array}{l}56 \\
28\end{array}$ & $\begin{array}{r}30 \\
6\end{array}$ & $\begin{array}{l}\text { NI } \\
\text { NC(V) }\end{array}$ & $\begin{array}{r}30 \\
1\end{array}$ & $\begin{array}{l}+(\mathrm{V}) \\
\mathrm{NC}\end{array}$ \\
\hline 21 & $\begin{array}{r}\text { II. } 1 \\
\text { III. } 1\end{array}$ & $\begin{array}{l}67 \\
33\end{array}$ & $\begin{array}{l}96 \\
24\end{array}$ & $\begin{array}{l}\text { NI } \\
\text { NI }\end{array}$ & $\begin{array}{l}96 \\
24\end{array}$ & $\begin{array}{l}+(\mathrm{S}) \\
+(\mathrm{S})\end{array}$ \\
\hline 22 & $\begin{array}{r}\text { I. } .4 \\
\text { II } .2 \\
\text { II } .3\end{array}$ & $\begin{array}{l}56 \\
28 \\
28\end{array}$ & $\begin{array}{l}94 \\
92 \\
24\end{array}$ & $\begin{array}{l}\text { NI } \\
\text { C(V) } \\
\text { NC(V) }\end{array}$ & $\begin{array}{r}94 \\
94 \\
2\end{array}$ & $\begin{array}{l}+(V) \\
+(V) \\
\text { NC }\end{array}$ \\
\hline 23 & $\begin{array}{r}\text { II } .3 \\
\text { III } .2\end{array}$ & $\begin{array}{l}56 \\
28\end{array}$ & $\begin{array}{r}30 \\
6\end{array}$ & $\begin{array}{l}\text { NI } \\
\text { C(S) }\end{array}$ & $\begin{array}{l}30 \\
29\end{array}$ & $\begin{array}{l}+(\mathrm{S}) \\
\mathrm{NI}\end{array}$ \\
\hline 24 & $\begin{array}{r}\text { II } .2 \\
\text { II. } 5 \\
\text { II. } 7 \\
\text { III. } 2\end{array}$ & $\begin{array}{r}6 \\
56 \\
6 \\
28\end{array}$ & $\begin{array}{r}1 \\
29 \\
1 \\
6\end{array}$ & $\begin{array}{l}\mathrm{NC}(\mathrm{V}) \\
\mathrm{NI} \\
\mathrm{NC}(\mathrm{V}) \\
\mathrm{NC}(\mathrm{V})\end{array}$ & $\begin{array}{l}<1 \\
29 \\
<1 \\
<1\end{array}$ & $\begin{array}{l}\text { NC } \\
+(\mathrm{V}) \\
\mathrm{NC} \\
\mathrm{NC}\end{array}$ \\
\hline 25 & $\begin{array}{r}\text { I. } .3 \\
\text { II. } .5\end{array}$ & $\begin{array}{l}60 \\
30\end{array}$ & $\begin{array}{l}35 \\
18\end{array}$ & $\begin{array}{l}\text { NI } \\
\mathrm{C}(\mathrm{V})\end{array}$ & $\begin{array}{l}35 \\
33\end{array}$ & $\begin{array}{l}+(\mathrm{V}) \\
\text { NI }\end{array}$ \\
\hline 26 & $\begin{array}{r}\text { II } .2 \\
\text { III. } 1 \\
\text { III } .2\end{array}$ & $\begin{array}{l}60 \\
30 \\
30\end{array}$ & & $\begin{array}{l}\mathrm{NI} \\
\mathrm{NC}(\mathrm{V}) \\
\mathrm{C}(\mathrm{V})\end{array}$ & $\begin{array}{r}60 \\
3 \\
57\end{array}$ & $\begin{array}{l}+(V) \\
N C \\
+(V)\end{array}$ \\
\hline 27 & $\begin{array}{l}\text { II. } 1 \\
\text { II. } 2 \\
\text { II. } 4 \\
\text { II. } 5\end{array}$ & $\begin{array}{r}8 \\
38 \\
4 \\
8\end{array}$ & $\begin{array}{r}3 \\
89 \\
2 \\
3\end{array}$ & $\begin{array}{l}\mathrm{NC}(\mathrm{W}) \\
\mathrm{NI} \\
\mathrm{NC}(\mathrm{W}) \\
\mathrm{NC}(\mathrm{W})\end{array}$ & $\begin{array}{l}<1 \\
89 \\
<1 \\
<1\end{array}$ & $\begin{array}{l}\text { NC } \\
+(W) \\
N C \\
N C\end{array}$ \\
\hline 28 & II. 1 & 60 & 34 & NI & 34 & $+(\mathrm{V})$ \\
\hline
\end{tabular}

For abbreviations see table 1 and footnotes to table 2. 
in other females at risk. In total 47 females at risk of being carriers were studied. Carriership could be excluded in 17 of these women using pERT87 probes, in three using D2, and in one using 754. In six females RFLP segregation was compatible with carriership and in 18 females including 16 mothers carriership could neither be confirmed nor excluded. In two females from family 12 carriership could indeed be confirmed because the segregation of pERT87-15 indicated that they had one $X$ chromosome with a deletion (see below). Of 23 females under the age of 45 and with a higher than $10 \%$ risk of being carriers, heterozygosity for an RFLP enabling us to offer prenatal studies was found in 21. Of these females 20 were heterozygous for a pERT87 probe and one for D2. By prenatal diagnosis and elective abortion, the birth of an affected male can be prevented, but the male fetuses with the same $X$ chromosome as the affected boys are not necessarily affected. So far we have made one prenatal study in a pregnancy at risk in a woman belonging to this category. The carrier risk estimates and the possibilities of prenatal diagnosis are presented in table 3.

\section{Example: family 24}

In this family with one affected male aged 15 (III.1), his sister (III.2) and two other women (II.2 and II.7) are at risk of being carriers. II. 2 and II.7 have different fathers. The mother and grandmother of the affected male are heterozygous for the BstXI RFLP of pERT87-8. Because II.7 is homozygous V1, the grandfather (I.4) must have been V1. The V2 allele of the affected male has thus been inherited from his grandmother. The mother's (II.5) carriership cannot be assessed. Since both of the mother's sisters (II.2 and II.7) and the sister of the affected male (III.2) have the X chromosome with the V1 allele, none of these three women is a carrier.

BECKER MUSCULAR DYSTROPHY, FAMILIAL

There were four BMD families with more than one affected male. A total of 12 affected males, seven obligate carrier females, and 15 females at risk of being carriers was studied. In this group all analyses were based on pERT 87 probes. Carriership could be excluded in nine females. RFLP segregation was compatible with carriership in six females at risk. We were able to offer prenatal determinations in subsequent pregnancies to the two obligate carrier females under the age of 45 and three additional females with a high risk of being carriers. The carrier risk estimates and the possibilities of prenatal diagnosis are shown in table 4.

Example: family 29

In this BMD family there have been six known affected males of whom four are alive. They are aged $45,42,28$, and 26 . The females I.2, II.2, and II. 6 are obligate carriers. The affected males all

TABLE 4 Carrier risk estimates and possibility of prenatal diagnosis using family data, CK measurements, and DNA studies in females at risk of being carriers in familial BMD.

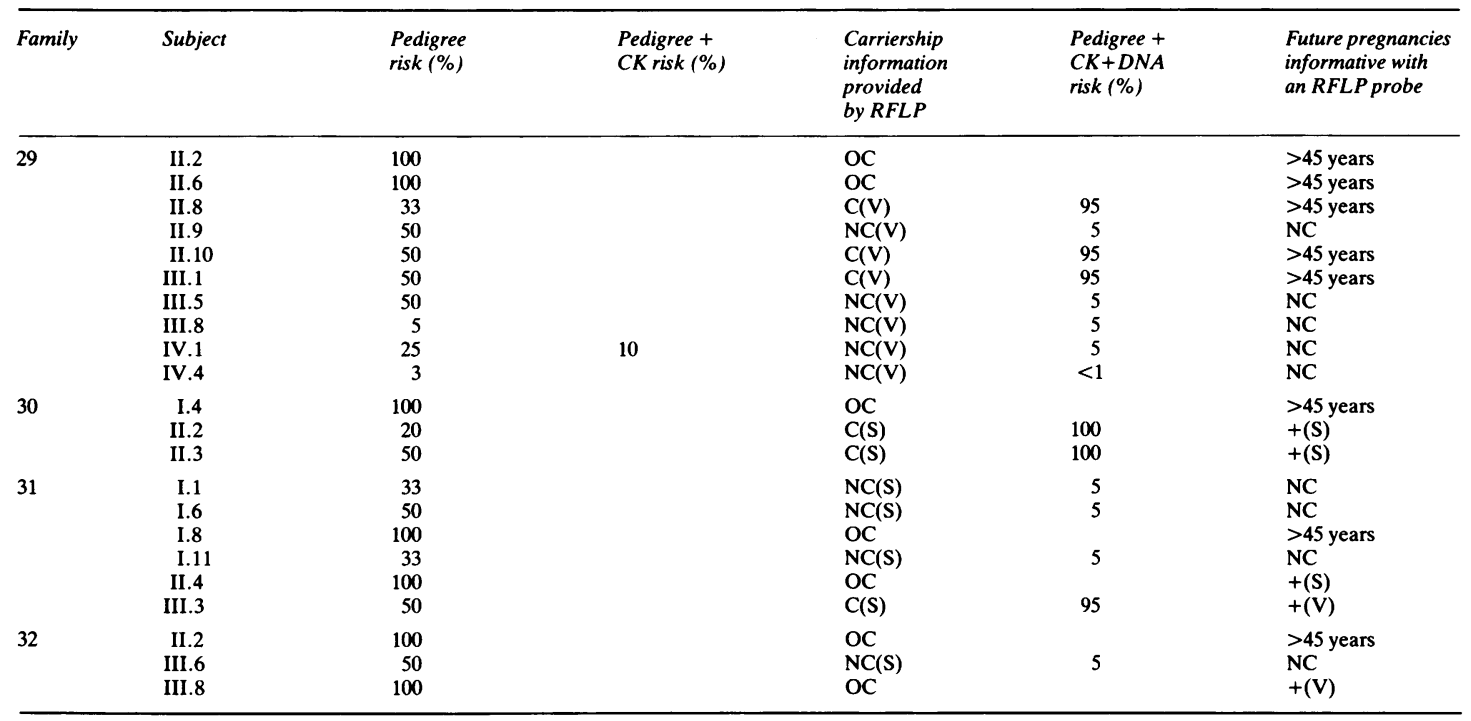

For abbreviations see table 1 and footnotes to table 2 . 
carry the V2 allele for the BstXI RFLP of pERT878. Subject III.1 has inherited the V2 allele from her mother which is compatible with carriership. Her daughter (IV.1) is homozygous V1 and is not a carrier. As III.1 is heterozygous prenatal diagnosis in further pregnancies would have been possible; however, this woman is now aged 47. III.5, a sister of two affected males, has received the V1 allele from her mother so carriership can be excluded. Since female II.9 is homozygous V1, the grandfather (I.1) must have been V1 and the grandmother (I.2) heterozygous V1-2. II.9 is thus not a carrier but her heterozygous sisters II. 8 and II.10 are carriers. On the other hand, III.8 is not a carrier since she has inherited V1 from her carrier mother (II.8).

BECKER MUSCULAR DYSTROPHY, SPORADIC Of a total of six BMD families, in two there was only one affected male and a negative family history. Of seven women at risk of being carriers carriership could be excluded in six using a pERT 87 probe. In family 33 the mother is not a carrier for the same reason as in family 19 . No new possible carrier females were detected in these two families. We were able to offer prenatal diagnosis to the only possible carrier female in this group using probe pERT87-8. The results are presented in table 5.

\section{Example: family 34}

In this BMD family with one affected male aged 25 , carrier analysis and prenatal diagnosis had been attempted earlier based on probe D2 ${ }^{17}$ Subject II.3 was pregnant and sought advice. We concluded that she was not a carrier, the pregnancy continued, and she is now the mother of a healthy son (III.4). Results with probe pERT87-8 corroborate the previous conclusion. The affected male as well as his mother have the V1 allele for the BstXI RFLP. The dead grandmother must have had at least one V2 allele. It can not be assessed if the mother is a carrier, but if she is, then the $\mathrm{X}$ chromosome with the $\mathrm{BMD}$ mutation is the paternally derived one carrying V1. Alternatively the mother is not a carrier and the mutation occurred at gametogenesis. Both alternatives exclude the grandmother as a carrier and so her other daughters II. 3 and II.4 are not carriers.

GENETIC COUNSELLING BASED ON DELETIONS In one sporadic DMD family (12) and one familial BMD family (30) the probands had deletions involving all three pERT87 probes. We assume that the disease in these cases is caused by the deletion. ${ }^{20}$

In family 12 RFLP studies with pERT87-15 showed that not only the mother (II.2) of the affected male, aged 7 (III.3), but also the grandmother (I.2), is a carrier of the deleted X chromosome. The grandmother (I.2) must be hemizygous for the S1 allele since the mother (II.2) does not have this allele and only has the S2 allele from the grandfather (I.1). The sister and brother (II.3 and II.4) of the mother have inherited the normal $X$ from the grandmother. The sister (III.1) of the affected male has an $X$ chromosome with the Q1 and $S 2$ alleles. Since one $X$ chromosome of a female is from her father and since III.1 does not have any Q2 allele she must have another biological father. Subsequently paternity determinations using ABO and several other blood groups exclude II.1 as the father of III.1 (courtesy of Dr P A Tippett, MRC Blood Group Unit, London). We conclude that III. 1 is a carrier of the deletion since she does not have the Q2 allele from her mother but instead has the $\mathrm{X}$ chromosome with the deletion.

In family 30 all three living affected males, aged 28, 26, and 26 (II.4, II.5, and II.6) have the deletion. They became wheelchair bound at 15, 13, and 13 years, respectively. At this stage considerable muscular strength was still preserved but fixed contractures of the ankles prevented the patients

TABLE 5 Carrier risk estimates and possibility of prenatal diagnosis using family data, CK measurements, and DNA studies in females at risk of being carriers in sporadic BMD.

\begin{tabular}{|c|c|c|c|c|c|c|}
\hline Family & Subject & $\begin{array}{l}\text { Pedigree } \\
\text { risk }(\%)\end{array}$ & $\begin{array}{l}\text { Pedigree + } \\
\text { CK risk (\%) }\end{array}$ & $\begin{array}{l}\text { Carriership } \\
\text { information } \\
\text { provided } \\
\text { by RFLP }\end{array}$ & $\begin{array}{l}\text { Pedigree + } \\
C K+D N A \\
\text { risk }(\%)\end{array}$ & $\begin{array}{l}\text { Future pregnancies } \\
\text { informative with } \\
\text { an RFLP probe }\end{array}$ \\
\hline 33 & $\begin{array}{r}\text { II } .2 \\
\text { III. } 2 \\
\text { III. } 4\end{array}$ & $\begin{array}{l}35 \\
18 \\
18\end{array}$ & $\begin{array}{r}16 \\
8 \\
8\end{array}$ & $\begin{array}{l}\mathrm{NC}(\mathrm{S}) \\
\mathrm{NC}(\mathrm{S}) \\
\mathrm{NC}(\mathrm{S})\end{array}$ & $\begin{array}{l}2 \\
1 \\
1\end{array}$ & $\begin{array}{l}\mathrm{NC} \\
\mathrm{NC} \\
\mathrm{NC}\end{array}$ \\
\hline 34 & $\begin{array}{r}\text { II. } 1 \\
\text { II } .3 \\
\text { II. } 4 \\
\text { III. } 3\end{array}$ & $\begin{array}{r}50 \\
13 \\
4 \\
7\end{array}$ & $\begin{array}{r}26 \\
3 \\
2\end{array}$ & $\begin{array}{l}\text { NI } \\
\text { NC(V) } \\
\text { NC(V) } \\
\text { NC(V) }\end{array}$ & $\begin{array}{l}26 \\
<1 \\
<1 \\
<1\end{array}$ & $\begin{array}{l}+(\mathrm{V}) \\
\mathrm{NC} \\
\mathrm{NC} \\
\mathrm{NC}\end{array}$ \\
\hline
\end{tabular}

The Bayesian calculations were performed in the same way as in the DMD families.

For abbreviations see table 1 and footnotes to table 2 . 
from walking. At present they can still use their arms and their intelligence is normal. Since there was an affected male in generation I, the maternal grandmother of the living patients must have been an obligate carrier. Genetic counselling could be given in this family using the TaqI RFLP of probe pERT87-15. Both sisters of the affected males (II.2 and II.3) have inherited the deleted X chromosome from their mother since autoradiographs show only the S2 allele from their father. Further pregnancies with a male fetus can be scored by the presence or absence of the DNA fragment hybridising with probe pERT87-15 in these two families.

\section{Discussion}

Genetic counselling of women at risk of being carriers in families with DMD and BMD patients has been both difficult and unsatisfactory. There has been no reliable method of carrier detection and during pregnancy nothing more than prenatal sex determination has been available. Cloned DNA fragments from the short arm of the X chromosome have opened new possibilities for detecting carriers and affected fetuses. The first RFLP probes showing medium linkage (15 to $20 \mathrm{cM}$ ) to the disease locus, $\mathrm{RC} 8(D X S 9)$ and L1.28 (DXS7), were isolated in the first half of the $1980 \mathrm{~s}^{7}{ }^{14} 31$ Since then, over a dozen more RFLP probes have been identified, some of which are somewhat more closely linked (5 to $10 \mathrm{cM}$ ) to the disease locus.

The real breakthrough was made in 1985 when Kunkel et $a l^{19}$ cloned DNA fragments from a DMD male with a small, visible interstitial deletion of the short arm of the X chromosome. These DNA fragments are probably located within a critical region in which point mutations or deletions cause $\mathrm{X}$ linked muscular dystrophy. The locus is called DXS164. The seven RFLPs of pERT87 subclones 1 , 8 , and 15 that we have had access to have been quite informative in the Finnish DMD and BMD families studied. Of a total of 97 females at risk of being carriers studied, segregation analysis of the pERT87 probes gave information that could be used in genetic counselling in $64(66 \%)$, and of a total of 52 obligate or possible carriers under the age of 45 prenatal diagnosis using these probes is possible in $45(87 \%)$.

In this study, approximately one-third of the families with DMD and BMD in Finland were investigated. The sampling of the families was unbiased with respect to familial or sporadic cases, so our series should be representative of $\mathrm{X}$ linked muscular dystrophy families wishing to be counselled. One problem was to determine whether the patient had DMD or BMD. The age at becoming wheelchair bound was used in the classification. Patients who were confined to a wheelchair before the age of 12 were considered to have DMD and patients who were able to walk after 12 were regarded as having BMD. These criteria are widely used and even generally accepted. ${ }^{22}$ Yet some patients were difficult to classify as they lost their ability to walk around or soon after 12 years, that is, too late for DMD and much too early for classical BMD. We believe that subdividing $X$ linked muscular dystrophy into DMD and BMD may be not only difficult but also useless. In $\mathrm{X}$ linked muscular dystrophy the patients' symptoms seem to form a continuous spectrum and the severity of the disease may or may not depend on the site and nature of the mutation. Some of the patients now classified as DMD or BMD may even have another disorder, $\mathrm{X}$ linked or not. Perhaps the most illustrative evidence of how futile it is to divide patients into DMD and BMD is the fact that some patients under the age of 12 by definition cannot be classified.

No point mutations have been identified or characterised but at least 88 deletions have already been seen. ${ }^{20}$ In a diagnostic situation it is usually unknown in which direction the particular mutation occurs relative to $\dot{D} X S 164$. It has been estimated that $D X S 164$ will be in error in predicting the DMDE $\mathrm{X}$ chromosome about $5 \%$ of the time. ${ }^{20}$ This can be due to several unrelated reasons, such as (1) recombination; (2) heterogeneity, that is, the occasional occurrence of mutations in other $\mathrm{X}$ linked or even autosomal loci causing phenotypes similar to DMD and BMD; or (3) new mutations in families where DMD or BMD has already occurred. One apparent recombination between DXS164 and familial DMD was observed in our series. In family 7 the two affected brothers had different alleles for the BstXI polymorphism of probe pERT87-8. This is an important example of a family in which prediction based on pERT87-8 in the mother's last pregnancy would have been wrong. This phenomenon may be due to recombination but alternative explanations listed above can not be excluded. At present, no error free or almost error free method is available except for predictions in male offspring of carriers of deletions.

In our predictions of carrier risk we have emphasised findings obtained with the probe (or family of probes) most closely linked to the disease locus, that is, pERT87. We show that numerous women at risk of being carriers can be shifted into low or high risk groups using this strategy. It has been shown by others that similar results can be obtained using flanking probes at greater distance from the disease locus. For instance, in two families, Bakker et $a^{15}$ tested as many as 11 probes to identify flanking 
RFLPs showing heterozygosity in relevant family members. In a large study of 73 sisters of DMD patients, Williams et $\mathbf{l}^{13}$ studied four probes distal to and three proximal to DMD. Informative flanking markers occurred in 53 of the women and could be used to modify the risk estimates significantly. We have not tried to use a pERT87 RFLP and another RFLP as flanking markers because in most cases the orientation (proximal or distal) of pERT87 relative to the disease locus is not known. Moreover, except for probes 754 and OTC, the linked probes used by most researchers ${ }^{11-17}$ are either relatively far away from DMD (for example, probes 782, D2, and L1.28) or have a low heterozygote frequency (for example, probes RC8, 99-6, and C7), making their use either difficult or impossible.

In females at risk there was no disagreement between pedigree information, clearly raised $\mathrm{CK}$ values, and pERT87 results. As expected, normal CK values were seen in several females who had a high risk of being carriers by DNA studies. At present there are situations in which we find it difficult to combine the information obtained by different methods. For instance, should a high CK value in a woman whose carriership had been 'excluded' by DNA studies be considered a proof of recombination? What is the significance of unstudied healthy sons in estimating their mother's possible carriership? For example, in family 10 , the conventionally determined risk of being a carrier of the female II.1 based on pedigree information was substantially lowered by her three healthy sons. We now know that the sons have inherited X chromosomal material close to the DMD locus (pERT87) from their grandfather and thus the fact that they are unaffected hardly alters their mother's risk of being a carrier at all. We hope that the relative value of various types of information will be better understood when more comprehensive studies of this type have been done.

Most of the females at risk in these 34 families had been counselled before this study by clinical geneticists or paediatricians. Carriership risks had been calculated using the information obtained from the pedigrees with or without CK determinations. After this study the families were counselled using RFLP information in addition to pedigree and CK information. The change in risk estimate is shown in fig $2 a$ and $b$. After this study many females who had earlier been counselled as having a medium risk could be shifted to a clearly high or low risk group on the basis of the RFLP results.

In our counselling we concentrated on informing the females about their risks and explained the possibilities for prenatal studies. We did not explain the principle of RFLP studies if the counsellees did

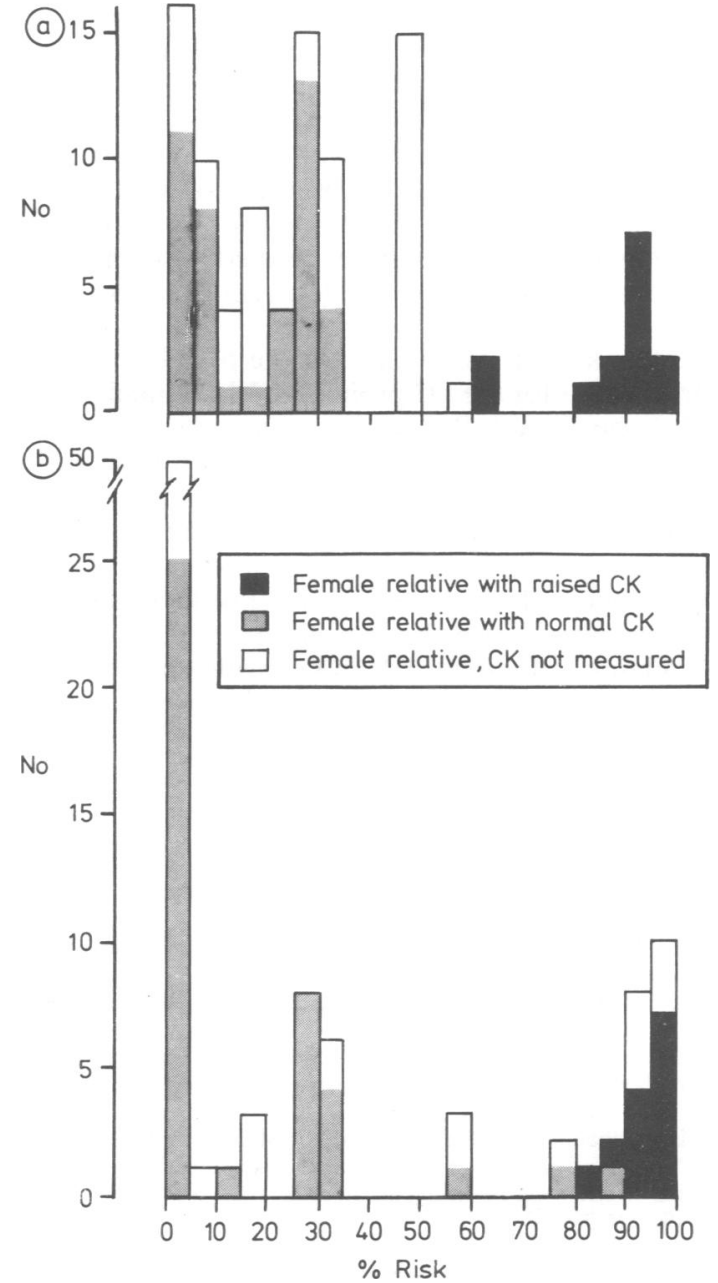

FIG 2 (a) Evaluation of the risk of 97 female relatives being carriers of the gene for DMD or BMD. Only data obtained from the pedigree and the $C K$ measurements were used. (b) Evaluation of the risk of the same 97 female relatives shown in (a) of being carriers of the gene for DMD or $B M D$. The data obtained from the pedigree and the $C K$ measurements were combined with the results of the RFLP studies.

not specifically ask. The risk of 'recombination' was explained as a risk of misinterpreting the results. As discussed above, only further studies will indicate what the real reasons for wrong predictions are. They may well turn out to be different in different cases. At counselling it was emphasised that these occasional difficulties of interpretation are insurmountable today but may soon be overcome when more becomes known about the gene and more probes become available. After verbal counselling 
each female received the same information in written form. It was indicated that the molecular biology involved is being rapidly explored and that the counsellees should contact us every time a new pregnancy was being planned or had started. Our impression was that the information of the risk was usually understood and most females at risk would want to have their future pregnancies studied even under the present not totally favourable circumstances.

We thank Dr L M Kunkel for the pERT87 probes, Dr S A Latt for the D2 probe, Dr J-L Mandel for the C7 probe, Dr P L Pearson for probes 754 and L1.28, and Dr P A Tippett for paternity determinations in family 12 . We also thank the physicians whose patients we were allowed to contact and the staff at many hospitals for collecting the samples. This study was supported by grants from the Finska Läkaresällskapet, the Sigrid Jusélius Foundation, and the Academy of Finland. EMBO provided a short term fellowship enabling ML to work for two months in the laboratory of KED.

\section{References}

1 Walton JN, Gardner-Medwin D. Progressive muscular dystrophy and the myotonic disorders. In: Walton JN, ed, Disorders of voluntary muscle. London: Churchill Livingstone, 1981:481524.

2 Emery AEH. Carrier detection in sex-linked muscular dystrophy. J Genet Hum 1965;14:318-29.

3 Lyon MF. Gene action in the X-chromosome of the mouse. Nature 1961;190:372-3.

4 Davie AM, Emery AEH. Estimation of proportion of new mutants among cases of Duchenne muscular dystrophy. $J$ Med Genet 1978;15:339-45.

5 Lindenbaum RH, Clarke G, Patel C, Moncrieff M, Hughes JT. Muscular dystrophy in an X;1 translocation female suggests that Duchenne locus is on $\mathrm{X}$ chromosome short arm. J Med Genet 1979;16:389-92.

6 Boyd Y, Buckle VJ. Cytogenetic heterogeneity of translocations associated with Duchenne muscular dystrophy. Clin Genet 1986;29:108-15.

7 Murray JM, Davies KE, Harper PS, Meredith L, Mueller CR, Williamson $R$. Linkage relationship of a cloned DNA sequence of the short arm of the X-chromosome to Duchenne muscular dystrophy. Nature 1982;300:69-71.

8 Kingston HM, Sarfarazi M, Thomas NST, Harper PS. Localisation of the Becker muscular dystophy gene on the short arm of the $\mathrm{X}$ chromosome by linkage to cloned DNA sequences. Hum Genet 1984;67:6-17.

9 Wilcox DE, Affara NA, Yates JRW, Ferguson-Smith MA, Pearson PL. Multipoint linkage analysis of the short arm of the human $\mathrm{X}$ chromosome in families with $\mathrm{X}$-linked muscular dystrophy. Hum Genet 1985;70:365-75.

10 Goodfellow P, Davies KE, Ropers HH. Report of the committee on the genetic constitution of the $\mathrm{X}$ and $\mathrm{Y}$ chromosomes. Cytogenet Cell Genet 1985;40:296-352.

11 Wieacker P, Davies KE, Pearson P, Ropers HH. Carrier detection in Duchenne muscular dystrophy by use of cloned DNA sequences. Lancet 1983;i:1325-6.

12 Harper PS, O'Brien T, Murray JM, Davies KE, Pearson P, Williamson $R$. The use of linked DNA polymorphisms for genotype prediction in families with Duchenne muscular dystrophy. J Med Genet 1983;20:252-4.
13 Williams H, Sarfarazi M, Brown C, Thomas N, Harper PS. The use of flanking markers in prediction for Duchenne muscular dystrophy. Arch Dis Child 1986;61:218-22.

14 Hofker MH, Wapenaar MC, Goor N, Bakker E, van Ommen GJB, Pearson PL. Isolation of the probes detecting RFLPs from $\mathrm{X}$-chromosome specific libraries. Potential use for diagnosis of DMD. Hum Genet 1985;70:148-56.

15 Bakker E, Goor N, Wrogemann K, et al. Prenatal diagnosis and carrier detection of Duchenne muscular dystrophy with closely linked RFLPs. Lancet 1985;i:655-8.

16 Kingston HM, Sarfarazi M, Newcombe RG, Willis N, Harper PS. Carrier detection in Becker muscular dystrophy using creatine kinase estimation and DNA analysis. Clin Genet 1985;27:383-91.

17 Lindlöf M, Ämmälä P, Somer H, Somer M, Simola KOJ, de la Chapelle A. Diagnosis of Duchenne muscular dystrophy by recombinant DNA-techniques. Duodecim 1985;101:2184-91.

18 Francke U, Ochs HD, de Martinville B, et al. Minor Xp21 chromosome deletion in a male associated with expression of Duchenne muscular dystrophy, chronic granulomatous disease, retinitis pigmentosa and McLeod syndrome. Am J Hum Genet 1985;37:250-67.

19 Kunkel LM, Monaco AP, Middlesworth W, Ochs HD, Latt SA. Specific cloning of DNA fragments absent from the DNA of a male patient with an X chromosome deletion. Proc Natl Acad Sci USA 1985;82:4778-82.

20 Kunkel LM, Hejtmancik JF, Caskey CT, et al. Analysis of deletions in DNA from patients with Becker and Duchenne muscular dystrophy. Nature 1986;322:73-7.

21 Ray PN, Belfall B, Duff C, et al. Cloning of the breakpoint of an $\mathrm{X} ; 21$ translocation associated with Duchenne muscular dystrophy. Nature 1985;318:672-5.

22 Emery AEH. The muscular dystrophies. In: Emery AEH Rimoin D, eds. Principles and practice of medical genetics Edinburgh: Churchill Livingstone, 1983:332-411.

23 Kunkel LM, Smith KD, Boyer SH, et al. Analysis of human Y-chromosome specific reiterated DNA in chromosome variants. Proc Natl Acad Sci USA 1977;74:1245-9.

24 Goossens M, Dumez Y, Kaplan L, et al. Prenatal diagnosis of sickle-cell anemia in the first trimester of pregnancy. $N$ Engl J Med 1983;14:831-3.

25 Page D, de la Chapelle A. The parental origin of $X$ chromosomes in $\mathrm{XX}$ males determined using restriction fragment length polymorphisms. Am J Hum Genet 1984;36:565-75.

26 Kunkel LM, Tantravahi U, Eisenhard M, Latt SA. Regional localisation on the human $X$ of DNA sequences cloned from flow sorted chromosomes. Nucleic Acids Res 1982;10:1557-61.

27 Camarino G, Koenig M, Moisan JP. Regional mapping of coagulation factor IX gene and several unique DNA sequences on the human X-chromosome. Cytogenet Cell Genet 1984;37:431-2.

${ }^{28}$ Monaco AP, Bertelson CJ, Middlesworth W, et al. Detection of deletions spanning the Duchenne muscular dystrophy locus using a tightly linked DNA segment. Nature 1985;316:842-5.

29 Wieacker P, Davies KE, Cooke HS, et al. Toward a complete linkage map of the human $\mathrm{X}$ chromosome: regional assignment of 16 cloned single-copy DNA sequences employing a panel of somatic cell hybrids. Am J Hum Genet 1984;36:256-76.

30 Murphy EA. The rationale of genetic counseling. $J$ Pediatr 1968;72:121-30.

31 Davies KE, Pearson PL, Harper PS, et al. Linkage analysis of two cloned DNA sequences flanking the Duchenne muscular dystrophy locus on the short arm of the human $\mathrm{X}$ chromosome Nucleic Acids Res 1983;11:2303-12.

Correspondence and requests for reprints to Professor A de la Chapelle, Department of Medical Genetics, University of Helsinki, Haartmaninkatu 3, SF-00290 Helsinki, Finland. 


\section{Discussion}

Lymphoedema, when inherited, develops due to the action of a dominant autosomal gene ${ }^{5}$ with incomplete penetrance of about $50 \%$. There is sex influence with a higher proportion of females developing lymphoedema $(\mathrm{M}: \mathrm{F}=0 \cdot 4)$. In the small number of patients with bilateral hyperplasia the sex influence seems to be reversed, with males at greater risk than females $(\mathrm{M}: \mathrm{F}=1 \cdot 7)$.

The possibilities that could explain the occurrence of distichiasis with bilateral hyperplasia are (1) that there is linkage of two genes, (2) that there are two pleiotropic effects of the same incompletely penetrant gene with variable expression, or (3) that this is simply association.

Distichiasis is a rare condition and it does occur separately from lymphoedema. Fox surveyed published reports in $1962^{6}$ and found 78 cases described. $\mathrm{He}$ found a strong hereditary influence without any sex predeliction but did not mention any connection with lymphoedema. McKusick ${ }^{7}$ quotes Maumenee (personal communication, 1982) that it is only where lymphoedema is also present that distichiasis is inherited. Published reports are confusing and this may be due to the variability of expression of the two traits, particularly the late onset of lymphoedema in many cases.

Bilateral hyperplasia is a rare form of a rare condition and it is unlikely that distichiasis would only appear in this small group from the effect of linkage. There is no reason to think that the combination has any effect on survival and linkage disequilibrium cannot explain the findings.
Association is an unlikely explanation for the two conditions to appear together as they are both rare and one would have expected distichiasis to occur with other forms of lymphoedema.

\section{Conclusion}

The appearance of distichiasis with primary lymphoedema is restricted to those with bilateral hyperplasia of the lymphatics. If distichiasis is seen in someone with lymphoedema, it is likely that patient has bilateral hyperplasia rather than other forms of lymphoedema. Distichiasis and bilateral hyperplasia appear to be inherited through the action of an incompletely penetrant gene with two pleiotropic effects and variable expression.

\footnotetext{
References

' Kinmonth JB. The lymphatics. London: Arnold, 1982:102.

2 Corbett CRR, Dale RF, Coltart DJ, Kinmonth JB. Congenital heart disease in patients with primary lymphoedemas. Lymphology 1982;15:85-90.

${ }^{3}$ Neel JV, Schull WJ. Human heredity. Chicago: University of Chicago Press, 1954:50-1.

${ }^{4}$ Kinmonth JB, Wolfe JH. Fibrosis in the lymph nodes in primary lymphoedema. Ann $R$ Coll Surg Engl 1980;62:344-54.

5 Dale RF. The inheritance of primary lymphoedema. J Med Genet 1985;22:274-8.

${ }^{6}$ Fox SA. Distichiasis. Am J Ophthalmol 1962;53:14-8.

7 McKusick VA. Mendelian inheritance in man. 6th ed. Baltimore: Johns Hopkins University Press, 1983:140.
}

Correspondence and requests for reprints to $\mathrm{Mr}$ R F Dale, FRCS, Senior Surgical Registrar, Addenbrooke's Hospital, Hills Road, Cambridge CB2 2QQ.

\section{Correction}

In the paper 'Carrier detection and prenatal diagnosis in $\mathrm{X}$ linked muscular dystrophy using restriction fragment length polymorphisms' by Lindlöf et al, published in the December 1986 issue of the Journal ( $J$ Med Genet 1986;23:560-72), an error occurred in fig 1. The pERT87 alleles underneath III.1 in family 5 should read S2, F2 and not S1, F2. 